\title{
STUDIES ON A NEW ANTIBIOTIC SF-2330
}

\section{THE STRUCTURAL ELUCIDATION}

\author{
Jiro Itoh, TADAshi Tsuyuki, Kayo Fujita \\ and MASAJI SEZAKI \\ Pharmaceutical Research Laboratories, \\ Meiji Seika Kaisha, Ltd., \\ Morooka-cho, Kohoku-ku, Yokohama 222, Japan \\ (Received for publication January 17, 1986)
}

\begin{abstract}
The structure of antibiotic SF-2330 has been elucidated to be 11-hydroxy-5-methyl-2(2,2'-bioxiran-2-yl)-4H-anthra[1,2-b]pyran-4,7,12-trione by spectral analyses. The olefinic side chain at C-2 of $\alpha$-indomycinone is replaced by a bioxiran-2-yl group in SF-2330.
\end{abstract}

A new antibiotic SF-2330 active against Gram-positive bacteria has been isolated from the culture of Streptomyces sp. SF-23301). In this paper, the structural elucidation by spectral analyses of the antibiotic is reported.

The molecular formula of antibiotic SF-2330 (1) was determined to be $\mathrm{C}_{22} \mathrm{H}_{14} \mathrm{O}_{7}$ from the elemental analysis, FD-MS $\left(\mathrm{M}^{+} \mathrm{m} / z\right.$ 390), ${ }^{1} \mathrm{H}$ and ${ }^{13} \mathrm{C}$ NMR spectra ${ }^{1)}$. The UV spectrum of $\mathbf{1}$ is very similar to those of indomycinones ${ }^{2)}$ and also the pluramycin group antibiotics, i.e., pluramycin ${ }^{3)}$, neopluramycin $^{4)}$, hedamycin ${ }^{2,5)}$, kidamycin ${ }^{2,8)}$, griseorubin ${ }^{7)}$, $\operatorname{largomycin}^{8)}$ and PD $121,222^{9)}$, and suggested the presence of similar chromophore in the molecule of $\mathbf{1}$. ${ }^{1} \mathrm{H}$ NMR spectrum of $\mathbf{1}$ indicated the presence of 14 protons containing five aromatic protons, three protons of one methyl group, four protons of two methylene groups, one proton of methine group and one proton of hydrogen-bonded hydroxyl group (Table 1).

IR spectrum of 1 showed strong absorption bands at 1675 (sh) and 1655 (quinone carbonyl and ketone $\mathrm{CO}$ ) and $1630 \mathrm{~cm}^{-1}$ (hydrogen-bonded quinone $\mathrm{CO}$ ). ${ }^{13} \mathrm{C}$ NMR spectrum of 1 showed the presence of 22 carbons containing two quinone $\mathrm{CO}$, one ketone $\mathrm{CO}, 14$ olefinic carbons, one methyl carbon, two methylene carbons, one methine carbon and one quaternary carbon (Table 2).

Acetylation of 1 gave a monoacetate (2), $\mathrm{C}_{24} \mathrm{H}_{18} \mathrm{O}_{8}, \mathrm{MS} \mathrm{m} / \mathrm{z} 432\left(\mathrm{M}^{+}\right)$. IR spectrum of 2 showed characteristic absorption bands at 1755 (acetyl CO), 1665 and $1640 \mathrm{~cm}^{-1}$ (quinone $\mathrm{CO}$ and pyrone CO). ${ }^{1} \mathrm{H}$ and ${ }^{13} \mathrm{C}$ NMR spectra of 2 (Tables 1 and 2$)$ revealed signals due to the acetyl group $(\delta 2.45 \mathrm{~s}$, $21.1 \mathrm{q}, 169.5 \mathrm{~s})$.

${ }^{1} \mathrm{H}$ NMR data of $\mathbf{1}$ are very similar to that of $O$-methylkidamycinone $(3)^{10)}$ and, in part, to those of members of the pluramycin group antibiotics, ${ }^{2,11,12}$. Three aromatic protons at $\delta 7.80,7.67$ and 7.35, observed as an $\mathrm{ABC}$ type spin system, was assigned to 8- $\mathrm{H}, 9-\mathrm{H}$ and $10-\mathrm{H}$, respectively (Fig. 1), by ${ }^{1} \mathrm{H}-{ }^{-1} \mathrm{H}$ decoupling experiments. The $8-\mathrm{H}$ proton $(\delta 7.80)$ appeared at low field because of the periposition of a quinone carbonyl. For the same reason, an unresolved quartet at $\delta 8.07$ was assigned to the 6-H proton which is allylic coupled to a methyl signal at $\delta 2.99(J=0.7 \mathrm{~Hz})^{22}$. The remaining aromatic proton at $\delta 6.53$ could be assigned to $3-\mathrm{H}$ from the chemical shift of $\gamma$-pyrone ${ }^{13)}$. These ${ }^{1} \mathrm{H}$ NMR assignments to the chromophore of 1 were confirmed by ${ }^{13} \mathrm{C}$ NMR data as follows. The signal of the quinone $\mathrm{CO}$ at $\delta 181.4(\mathrm{C}-7)$ was split into a triplet $(J=4 \mathrm{~Hz})^{2,14)}$, whereas the signal of another 
Table 1. ${ }^{1} \mathrm{H}$ NMR chemical shifts of SF-2330 (1) and monoacetate (2).

\begin{tabular}{lcl}
\hline \multirow{2}{*}{ Proton } & \multicolumn{1}{c}{$\delta, \mathrm{ppm}(J \mathrm{~Hz})$ in $\mathrm{CDCl}_{3}$} \\
\cline { 2 - 3 } & \multicolumn{1}{c}{$\mathbf{1}$} & \multicolumn{1}{c}{$\mathbf{2}$} \\
\hline $3-\mathrm{H}$ & $6.531 \mathrm{H}, \mathrm{s}$ & $6.501 \mathrm{H}, \mathrm{s}$ \\
$6-\mathrm{H}$ & $8.071 \mathrm{H}, \mathrm{q}(0.7)$ & $8.021 \mathrm{H}, \mathrm{s}$ \\
$9-\mathrm{H}$ & $7.801 \mathrm{H}, \mathrm{dd}(8.0,1.1)$ & $8.221 \mathrm{H}, \mathrm{d}(7.5)$ \\
$9-\mathrm{H}$ & $7.671 \mathrm{H}, \mathrm{dd}(8.4,8.0)$ & $7.791 \mathrm{H}, \mathrm{t}(8.0)$ \\
$10-\mathrm{H}$ & $7.351 \mathrm{H}, \mathrm{dd}(8.4,1.1)$ & $7.471 \mathrm{H}, \mathrm{d}(6.4)$ \\
$11-\mathrm{OH}$ & $12.731 \mathrm{H}, \mathrm{s}$ & $2.893 \mathrm{H}, \mathrm{s}$ \\
$15-\mathrm{H}$ & $2.993 \mathrm{H}, \mathrm{d}(0.7)$ & $4.141 \mathrm{H}, \mathrm{d}(6.2)$ \\
& $3.321 \mathrm{H}, \mathrm{d}(6.2)$ & $4.151 \mathrm{H}, \mathrm{d}(6.2)$ \\
$16-\mathrm{H}$ & $3.361 \mathrm{H}, \mathrm{d}(6.2)$ & $4.151 \mathrm{H}, \mathrm{dd}(3.6,2.7)$ \\
$17-\mathrm{H}$ & $4.171 \mathrm{H}, \mathrm{dd}(3.7,2.6)$ & $2.921 \mathrm{H}, \mathrm{dd}(5.6,2.7)$ \\
& $2.941 \mathrm{H}, \mathrm{dd}(5.5,2.6)$ & $2.941 \mathrm{H}, \mathrm{dd}(5.6,3.6)$ \\
$11-\mathrm{OCOCH}_{3}$ & $2.951 \mathrm{H}, \mathrm{dd}(5.5,3.7)$ & $2.453 \mathrm{H}, \mathrm{s}$ \\
\hline
\end{tabular}

Table 2. ${ }^{13} \mathrm{C}$ NMR chemical shifts of SF-2330 (1) and monoacetate (2).

\begin{tabular}{lcc}
\hline \multirow{2}{*}{ Carbon } & \multicolumn{2}{c}{$\delta, \mathrm{ppm} \mathrm{in} \mathrm{CDCl}_{3}$} \\
\cline { 2 - 3 } & $\mathbf{1}$ & 2 \\
\hline $1 \mathrm{a}$ & $156.2 \mathrm{~s}$ & $155.7 \mathrm{~s}$ \\
2 & $163.7 \mathrm{~s}$ & $163.7 \mathrm{~s}$ \\
3 & $111.2 \mathrm{~d}$ & $111.0 \mathrm{~d}$ \\
4 & $178.3 \mathrm{~s}$ & $180.2 \mathrm{~s}$ \\
$4 \mathrm{a}$ & $126.5 \mathrm{~s}$ & $126.7 \mathrm{~s}$ \\
5 & $150.0 \mathrm{~s}$ & $149.9 \mathrm{~s}$ \\
6 & $126.1 \mathrm{~d}$ & $125.5 \mathrm{~d}$ \\
$6 \mathrm{a}$ & $136.1 \mathrm{~s}$ & $135.3 \mathrm{~s}$ \\
7 & $181.4 \mathrm{~s}$ & $181.8 \mathrm{~s}$ \\
$7 \mathrm{a}$ & $132.1 \mathrm{~s}$ & $134.0 \mathrm{~s}$ \\
8 & $119.4 \mathrm{~d}$ & $125.5 \mathrm{~d}$ \\
9 & $136.6 \mathrm{~d}$ & $134.7 \mathrm{~d}$ \\
10 & $125.5 \mathrm{~d}$ & $130.5 \mathrm{~d}$ \\
11 & $162.6 \mathrm{~s}$ & $148.8 \mathrm{~s}$ \\
$11 \mathrm{a}$ & $116.6 \mathrm{~s}$ & $126.2 \mathrm{~s}$ \\
12 & $187.0 \mathrm{~s}$ & $178.5 \mathrm{~s}$ \\
$12 \mathrm{a}$ & $119.6 \mathrm{~s}$ & $121.4 \mathrm{~s}$ \\
13 & $24.1 \mathrm{q}$ & $24.0 \mathrm{q}$ \\
14 & $54.5 \mathrm{~s}$ & $54.5 \mathrm{~s}$ \\
15 & $53.7 \mathrm{t}$ & $53.7 \mathrm{t}$ \\
16 & $47.6 \mathrm{~d}$ & $47.6 \mathrm{~d}$ \\
17 & $45.1 \mathrm{t}$ & $45.0 \mathrm{t}$ \\
$11-\mathrm{OCO}_{11-O C O C H}$ & & $169.5 \mathrm{~s}$ \\
\hline & & $21.1 \mathrm{q}$ \\
\hline
\end{tabular}

quinone $\mathrm{CO}$ at $\delta 187.0(\mathrm{C}-12)$ was observed as a sharp singlet in a proton non-decoupled ${ }^{13} \mathrm{C}$ NMR spectrum. These results indicated that the $6-\mathrm{H}$ and $8-\mathrm{H}$ protons were located at the peri-position to the quinone $\mathrm{CO}$ at $\delta 181.4$, and the other quinone $\mathrm{CO}(\delta 187.0 \mathrm{~s})$ is assigned to $\mathrm{C}-12$ which is hydrogen-bonded to the $11-\mathrm{OH}$ ( $\delta 12.73 \mathrm{~s})$.

The structure of the side chain moiety comprising $\mathrm{C}_{4} \mathrm{H}_{5} \mathrm{O}_{2}$ remained to be defined. Index of unsaturation derived from the molecular formula is sixteen. Therefore, the presence of six rings in the structure of $\mathbf{1}$ in addition to ten unsaturated bonds observed in ${ }^{13} \mathrm{C}$ NMR spectrum is required. From the spectral results described above, the chromophore moiety accounts for four rings in the $4 H$-anthra[1,2-b]pyran structure. Thus, it is necessary to have two-ring structures in the side chain moiety. ${ }^{1} \mathrm{H}$ NMR spectrum of the side chain moiety showed five protons containing four methylene protons $(\delta$ $2.94,2.95,3.32,3.36$ ) and one methine proton ( $\delta$ 4.17). Methylene protons at $\delta 2.94$ and 2.95

is coupled with a methine proton at $\delta 4.17$, whereas another methylene pair at $\delta 3.32$ and 3.36 were not coupled to other protons. ${ }^{13} \mathrm{C}$ NMR spectrum of the side chain moiety showed four carbons containing two methylene carbons at $\delta 45.1(J=177 \mathrm{~Hz})$ and $53.7(J=180 \mathrm{~Hz})$, one methine carbon at $\delta$ $47.6(J=182 \mathrm{~Hz})$ and one quaternary carbon at $\delta 54.5$. The large coupling constants of two methylene carbons and one methine carbon indicated the presence of the two oxirane rings ${ }^{2,11,15)}$. From these results the structure of the side chain moiety was deduced as bioxiran-2-yl, shown in Fig. 1 . 
Fig. 1.<smiles>CCOc1cccc2c1C(=O)c1c(cc(C)c3c(=O)cc(Br)oc13)C2=O</smiles>

SF-2330 (1)

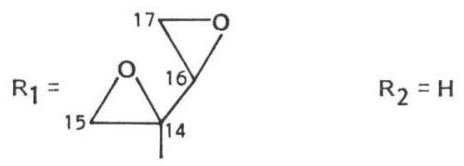

Monoacetate (2)

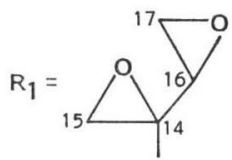

$\mathrm{R}_{2}=\mathrm{COCH}_{3}$

O-Methylkidamycinone

(3)<smiles>CC=C(C)C[In]</smiles>

$\mathrm{R}_{2}=\mathrm{CH}_{3}$

$\alpha$-Indomycinone

(4)

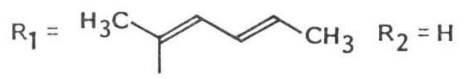

Observation of the long range couplings of a quaternary carbon (C-14 - 3-H, $J=3.1 \mathrm{~Hz}$ and $\mathrm{C}-14-16-\mathrm{H}$, $J=7.9 \mathrm{~Hz}$ ) confirmed by a long range selective proton decoupling experiment indicated that the side chain moiety must be located at C-2.

Although the stereochemistry of the side chain moiety is still undetermined, the structure of SF2330 has been shown to be 11-hydroxy-5-methyl-2-(2,2'-bioxiran-2-yl)-4H-anthra[1,2-b]pyran-4,7,12trione.

The unique bioxiran-2-yl side chain of SF-2330 is considered to be derived by oxygenation of the (E)-1-methyl-1-propenyl side chain of kidamycin. It is interesting that SF-2330, having this bioxiran2-yl side chain, showed some antibacterial activity against Gram-positive bacteria, whereas $\alpha$-indomycinone, having a 1-methylpenta-1,3-dienyl side chain, was biologically inactive ${ }^{18)}$.

\section{Experimental}

\section{Methods of Analysis}

Melting points were measured using a Yamato MP-21 and are uncorrected. UV spectra were measured on a Shimadzu UV-260 spectrometer. FD-MS were carried out on a Hitachi M-80. ${ }^{1} \mathrm{H}$ and ${ }^{13} \mathrm{C}$ NMR spectra were recorded on a Jeol JNM-GX $400\left({ }^{1} \mathrm{H} 400 \mathrm{MHz}\right.$ and $\left.{ }^{13} \mathrm{C} 100.7 \mathrm{MHz}\right)$ spectrometer; chemical shifts are given in ppm (in $\delta)$ relative to TMS $(0 \mathrm{ppm})$ as an internal standard and coupling constants $(J)$ are recorded in $\mathrm{Hz}$.

\section{SF-2330 Monoacetate (2)}

SF-2330 $(20 \mathrm{mg})$ was acetylated with acetic anhydride $(0.2 \mathrm{ml})$ in pyridine $(1 \mathrm{ml})$ at room temp for 85 hours. The reaction mixture was poured into ice cold water and allowed to stand for 1 hour. It was extracted with $\mathrm{CHCl}_{3}(10 \mathrm{ml})$ and the extract was washed with $\mathrm{H}_{2} \mathrm{O}$, dried over anhydrous $\mathrm{Na}_{2} \mathrm{SO}_{4}$ 
and concentrated to dryness under reduced pressure. The residue was chromatographed on a column of silica gel (Wakogel C-200, $1 \mathrm{~g}$ ) developed with benzene - $\mathrm{Me}_{2} \mathrm{CO}(10: 1)$ to give crude crystals (14 mg). Recrystallization from $\mathrm{CHCl}_{3}$ to yield $10 \mathrm{mg}$ of pale yellow needles of 2 ; mp $263 \sim 266^{\circ} \mathrm{C}(\mathrm{dec}) ; \mathrm{MS} \mathrm{m} / \mathrm{z}$ $291(100 \%), 432\left(\mathrm{M}^{+}, 36 \%\right)$. Anal Calcd for $\mathrm{C}_{24} \mathrm{H}_{18} \mathrm{O}_{8}: \mathrm{C} 66.54, \mathrm{H} 3.86$. Found: $\mathrm{C} 66.67, \mathrm{H} 3.73$; $\mathrm{UV} \nu_{\max }^{\mathrm{CHCl}} 372 \mathrm{~nm}(\varepsilon 10,270)$; IR $(\mathrm{KBr}) \mathrm{cm}^{-1} 1755,1665,1640,1630(\mathrm{sh}) ;{ }^{1} \mathrm{H}$ and ${ }^{13} \mathrm{C}$ NMR were shown in Tables 1 and 2, respectively.

\section{Acknowledgment}

The authors deeply thank to Dr. SHINICHI KonDo for his kind advice on the structural elucidation and his critical review of this manuscript.

\section{References}

1) Itoh, J.; T. Shomura, T. Tsuyuki, J. Yoshida, M. Ito, M. Sezaki \& M. Kojima: Studies on a new antibiotic SF-2330. I. Taxonomy, isolation and characterization. J. Antibiotics 39: 773 779, 1986

2) SÉquin, U.: The structure of the antibiotic hedamycin-II. Comparison of hedamycin and kidamycin. Tetrahedron 34: 761 767, 1978

3) Maeda, K.; T. Takeuch, K. Nitta, K. Yagishita, R. Utahara, T. Ōsato, M. Ueda, S. Kondō, Y. OKAMI \& H. UmeZAwa: A new antitumor substance, pluramycin. Studies on antitumor substances produced by actinomycetes. XI. J. Antibiotics, Ser. A 9: 75 81, 1956

4) Kondo, S.; T. Wakashiro, M. Hamada, K. Maeda, T. TaKeuchi \& H. Umezawa: Isolation and characterization of a new antibiotic, neopluramycin. J. Antibiotics 23: 354 359, 1970

5) Schmitz, H.; K. E. Crook, Jr. \& J. A. Bush: Hedamycin, a new antitumor antibiotic. I. Production, isolation and characterization. Antimicrob. Agents Chemother. -1966: 606 612, 1967

6) KANDA, N.: A new antitumor antibiotic, kidamycin. I. Isolation, purification and properties of kidamycin. J. Antibiotics 24: 599 606, 1971

7) Dornberger, K.; U. BERger \& H. KNöLl: Griseorubins, a new family of antibiotics with antimicrobial and antitumor activity. I. Taxonomy of the producing strain, fermentation, isolation and chemical characterization. J. Antibiotics 33: 1 8, 1980

8) Gonda, S. K.; K. M. Byrne, P. K. Herber, Y. Tondeur, D. Liberato \& B. D. Hilton: Structure and properties of major largomycin FII chromophore components. J. Antibiotics 37: 1344 1356, 1984

9) Nadig, H.; U. Séquin, R. H. Bunge, T. R. Hurley, D. B. Murphey \& J. C. French: Isolation and structure of a new antibiotic related to rubiflavin A. Helv. Chim. Acta 68: 953 957, 1985

10) Hauser, F. M. \& R. R. Rhee: 4H-Anthra[1,2-b]pyran antibiotics. Total synthesis of the methyl ether of kidamycinone. J. Am. Chem. Soc. 101: 1628 1629, 1979

11) Kondo, S.; M. Mryamoto, H. Naganawa, T. Takeuchi \& H. Umezawa: Structures of pluramycin A and neopluramycin. J. Antibiotics 30: 1143 1145, 1977

12) Furukawa, M.; I. Hayakawa, G. Оhta \& Y. Iitaka: Structure and chemistry of kidamycin. Tetrahedron 31: 2989 2995, 1975

13) Jackman, L. M. \& S. Sternhell: Applications of Nuclear Magnetic Resonance Spectroscopy in Organic Chemistry. 2nd Ed. pp. 172, 182, Pergamon Press, Oxford, 1969

14) SÉquin, U. \& M. Furukawa: The structure of the antibiotic hedamycin-III. ${ }^{13} \mathrm{C}$ NMR spectra of hedamycin and kidamycin. Tetrahedron 34: 3623 3629, 1978

15) Stothers, J. B.: Carbon-13 NMR Spectroscopy. p. 342, Academic Press, New York, 1972

16) BrockmanN, H.: Indomycins and indomycinones. Angew. Chem. Int. Ed. 7: 481, 1968 